US Army Corps

of Engineers

Waterways Experiment

Station

Environmental Security Technology Certification Program

\title{
Monitored Natural Attenuation of Explosives in Groundwater: Cost and Performance
}

by Judith C. Pennington, Mansour Zakikhani, Danny W. Harrelson, Daniel S. Allen 
The contents of this report are not to be used for advertising, publication, or promotional purposes. Citation of trade names does not constitute an official endorsement or approval of the use of such commercial products.

The findings of this report are not to be construed as an official Department of the Army position, unless so designated by other authorized documents. 


\section{Monitored Natural Attenuation of Explosives in Groundwater: Cost and Performance}

by Judith C. Pennington, Mansour Zakikhani, Danny W. Harrelson, Daniel S. Allen

U.S. Army Corps of Engineers

Waterways Experiment Station

3909 Halls Ferry Road

Vicksburg, MS 39180-6199

Final report

Approved for public release; distribution is unlimited

Prepared for Environmental Security Technology Certification Program Office 901 North Stuart Street

Suite 303

Arlington, VA 22203 


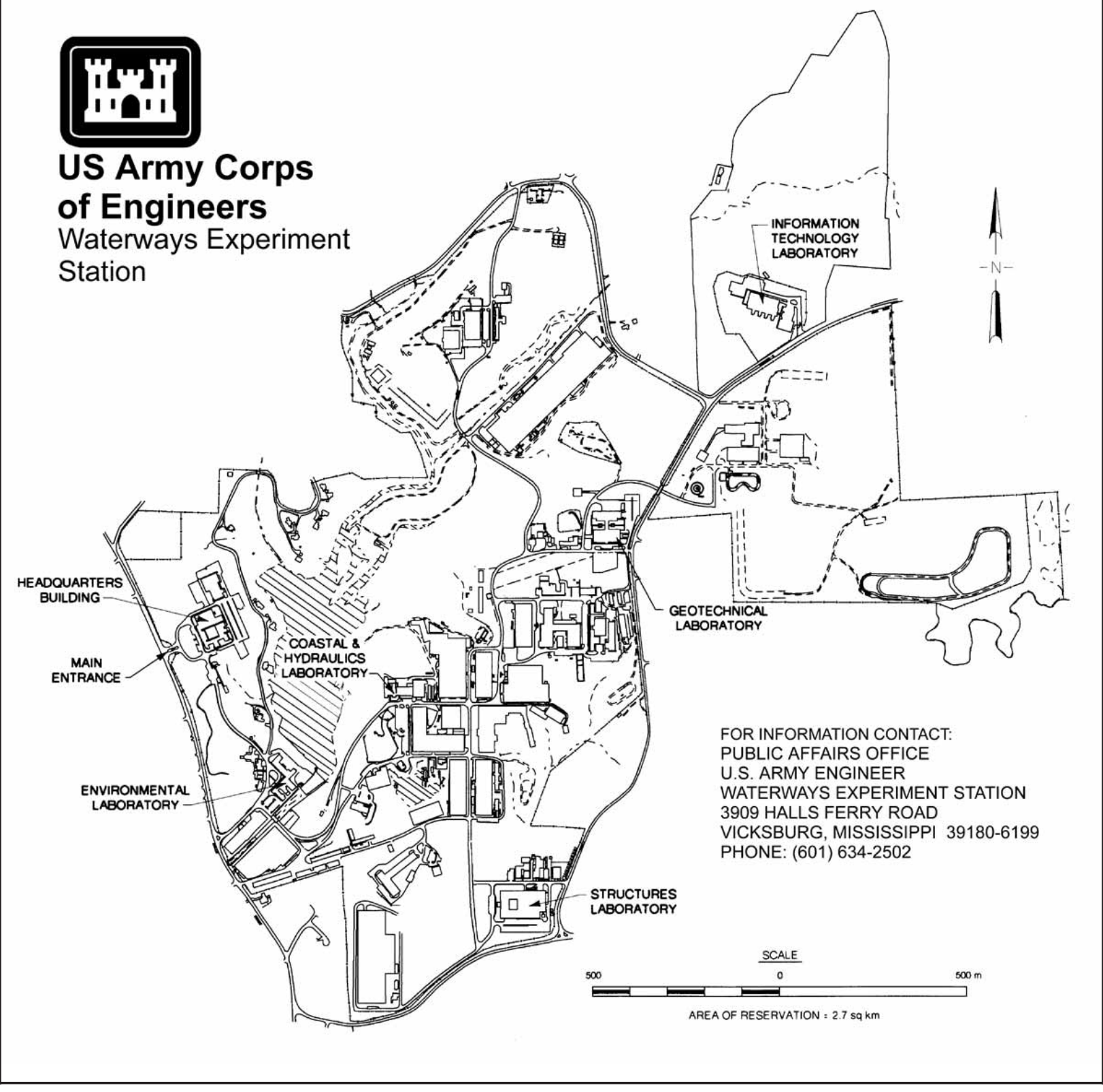

\section{Waterways Experiment Station Cataloging-in-Publication Data}

Monitored natural attenuation of explosives in groundwater : cost and performance / by Judith C.

Pennington ... [et al.] ; prepared for Environmental Security Technology Certification Program Office.

24 p. : ill. ; 28 cm. - (Technical report ; EL-99-9)

Includes bibliographical references.

1. Groundwater - Pollution. 2. Explosives, Military - Environmental aspects. 3. Hazardous wastes - Natural attenuation. 4. Soil remediation. I. Pennington, Judith C. II. United States. Army. Corps of Engineers. III. U.S. Army Engineer Waterways Experiment Station. IV. Environmental Laboratory (U.S. Army Engineer Waterways Experiment Station) V. Environmental Security Technology Certification Program (U.S.) VI. Series: Technical report (U.S. Army Engineer Waterways Experiment Station) ; EL-99-9.

TA7 W34 no.EL-99-9 


\title{
Monitored Natural Attenuation of Explosives in Groundwater - Cost and Performance U.S. Army Engineer Waterways Experiment Station
}

\author{
April 1999
}




\section{Preface}

This report was prepared by the Environmental Laboratory (EL) of the U.S. Army Engineer Waterways Experiment Station (WES), Vicksburg, MS. The demonstration was sponsored by the Environmental Security Technology Certification Program (ESTCP), Arlington, VA, Mr. Jeffrey Marqusee, Program Manager, Project Number 9518; and the Strategic Environmental Research and Development Program (SERDP), Arlington, VA, Dr. John Harrison and Mr. Bradley P. Smith, Executive Directors, Project Number 1043. The U.S. Army Industrial Operations Command, Rock Island, IL, Mr. Cyril Onewokae, Environmental Quality Directorate, funded monitoring at the validation site. The principal investigator was Dr. Judith C. Pennington, EL, WES.

The authors acknowledge the cooperation and site support received from Mr. Ira May, Mrs. Laurie Haines, and other personnel of the Army Environmental Center (AEC), Aberdeen Proving Ground, MD; Mr. Doyle Williams, Environmental Officer, Louisiana Army Ammunition Plant, Minden, LA; and Mr. Art Holz, Environmental Coordinator, Joliet Army Ammunition Plant, Joliet, IL. The authors also acknowledge the advice of the following members of the Technical Review Committee for Natural Attenuation of Explosives: Mr. Michael Barden, Geosciences Resources LTD, Albuquerque, NM, formerly of Wisconsin Department of Natural Resources, Madison, WI; Mr. Patrick Haas, U.S. Air Force Center for Environmental Excellence, San Antonio, TX; Mrs. Laurie Haines; and Dr. David C. White, University of Tennessee, Knoxville, TN.

The project represents the collective efforts of the following:

Groundwater Monitoring and Cone Penetrometry

Site Capacity and Geochemistry

Microbial Biomarkers

Groundwater Modeling

Statistics

Initial Draft Protocol
Danny W. Harrelson, Judith C. Pennington, WES; Thomas F. Jenkins, U.S. Army Cold Regions Research and Engineering Laboratory; Charolett A. Hayes, AScI Corporation, Vicksburg, MS

James M. Brannon, Tommy Myers, WES; Dan M. Townsend, North Carolina State University, Raliegh

Douglas Gunnison, Herb Fredrickson, WES; Ed Perkins, AScI; Dave Ringelberg, DynTel

Mansour Zakikhani, WES

Joan U. Clarke, WES

Rick Bowen, Janet Mahannah, Scot Gnewuch, Arthur D. Little, Inc., Cambridge, MA

This report was prepared by Drs. Pennington and Zakikhani, EL; Mr. Harrelson, Geotechnical Laboratory, WES; and Mr. Daniel S. Allen, EL, and was reviewed by Drs. James M. Brannon and William B. Davis, EL. The study was conducted under the direct supervision of Dr. Richard E. Price, Chief, Environmental Processes and Effects Division, EL, and Dr. John Harrison, Director, EL.

At the time of publication of this report, Acting Director of WES was COL Robin R. Cababa, EN. This report should be cited as follows:

Pennington, J. C., Zakikhani, M., Harrelson, D. W., and Allen, D. S. (1999). "Monitored natural attenuation of explosives in groundwater: Cost and performance," Technical Report EL-99-9, U.S. Army Engineer Waterways Experiment Station, Vicksburg, MS. 


\section{Executive Summary}

Monitored natural attenuation (MNA) is a remedial alternative for explosives-contaminated groundwater at sites where a decline in contaminant mass can be demonstrated to occur at a rate sufficient to ensure the protection of potential receptors. MNA is not a "no-action" alternative, but requires careful characterization of the site hydrogeology and contaminant distribution, long-term monitoring of groundwater, and groundwater modeling to conceptualize the contaminant plume and to predict future migration and attenuation. MNA in the context of the demonstration described herein does not include intervention to promote natural processes.

Demonstrating that MNA is a viable remedial alternative requires gathering a "weight of evidence" that natural processes are sufficient to protect receptors of concern within a reasonable time frame. Explosives are subject to several attenuation mechanisms that effectively reduce concentrations in natural systems. Some of these processes have been defined, while other are poorly understood. MNA relies upon quality site characterization data, carefully conducted long-term monitoring, and groundwater modeling for contaminant conceptualization and long-term predictions of contaminant fate. Determining attenuation rates for explosives requires demonstration of declining mass over time, and conservative extrapolation of attenuation capacity and microbial degradation potential from the laboratory to the field.

This demonstration was designed to define and optimize the data collection and processing procedures for evaluation, selection, and implementation of MNA for explosives. The demonstration was conducted at a former waste disposal lagoon site at the Louisiana Army Ammunition Plant, Minden, LA. Thirty wells were monitored quarterly over a 2-year period. A cone penetrometry sampling event was also conducted to refine the conceptualization of the site hydrogeology and to collect aquifer material for development of microbial biomarker techniques for tracking attenuation processes. A conceptual model of the contaminant plume was developed and a numerical model was used to predict future plume migration and mass.

Overall costs of the demonstration were approximately $\$ 4$ million. Refinements in sampling protocols, biomarker techniques, and modeling generated data that were sufficiently reliable for measuring and projecting trends in contaminant mass over time.

The overall cost (including pretreatment, treatment, and after-treatment costs) of MNA is projected to be about 25 percent lower than the cost of in situ bioremediation, and about 50 percent lower than the cost of pump-and-treat using activated carbon adsorption over 20 years (Pennington, Zakakhani, and Harrelson 1999; Member Agencies of the Federal Remediation Technologies Roundtable 1995). However, if the treatment time is extended and only treatment costs (exclusive of pretreatment and after-treatment costs) are used, cost savings from MNA over these other technologies increase over time. Treatment costs of MNA were 82 percent less than costs of in situ bioremediation and 88 percent less than costs of pump-and-treat remediation after 60 years. Therefore, the time required to achieve cleanup goals contributes significantly to the long-term cost savings of MNA.

\section{Technology Description}

\section{A. Background}

Natural attenuation is defined as reduction of contaminant concentrations to environmentally benign levels through natural processes. Natural attenuation as a remedial alternative can be evaluated along with engineered remedies. Monitored natural attenuation (MNA) may be a viable candidate remedy at sites where contaminant concentration is so low that other remedial actions are not viable or cost-effective, contaminant source has been remediated by engineered approaches leaving behind a low-level residue, contaminant attenuation has been demonstrated by existing site historical data, and/or the site is remote 
from receptors of immediate concern. MNA is attractive for sites where disturbance of structures or sensitive habitat is undesirable, and/or immediate engineered remedial action is not required or not feasible. MNA may be useful at sites that meet well-defined selection criteria and acceptable risk levels, and that satisfy specific regulatory concerns.

\section{B. Theory}

Explosives are subject to several environmental fate processes that may result in attenuation or reduction in the mass of contaminants in the groundwater. Some of these processes have been defined, while others are poorly understood. These processes occur through biotic or abiotic transformations of 2,4,6-trinitrotoluene (TNT) to aminonitrotoluenes, which are subject to immobilization by reaction with soil organic matter and exchange sites on clays, and microbial mineralization of hexahydro-1,3,5-trinitro1,3,5-triazine (RDX) to simple, nonhazardous inorganic compounds. Immobilization and degradation can be demonstrated by proving that the contaminant plume is moving significantly more slowly than would be predicted by the flow rate of the groundwater, and by demonstrating that the total estimated mass of contamination is declining over time. Degradation/transformation can be demonstrated by identifying products of these processes during groundwater monitoring.

Potential disadvantages of MNA include the long time frames likely to be required to meet remediation goals, the necessity for institutional controls of the site, and the potential for unexpected changes in local groundwater hydrogeology over the extended monitoring period.

\section{Specifications}

\section{Performance}

The primary technical performance criteria are described under Section III.A.3. "Performance Metrics," and are presented in the Demonstration Plan (Pennington et al. unpublished).

\section{Personnel/Training Requirements}

All personnel are required to take the standard Hazardous Waste Site Worker course plus annual refresher courses if the site is classified under Superfund. Training may be desirable for optimal well sampling using recommended standard operating procedures including purging well water before sampling, sample preservation and handling, and microsampling if biomarkers are investigated (Pennington et al. unpublished; Pennington et al. 1999a).

\section{Health and Safety Requirements}

The following three primary hazards are associated with implementation of MNA of explosives: (a) chemical and health hazards associated with exposure to explosives or their breakdown products, (b) normal field work hazards such as heat and cold exposure, heavy lifting, and working around drilling rigs and cone penetrometry trucks, and (c) normal laboratory hazards such as handling flammable solvents. Minimal hazard of explosion exists for explosives-contaminated groundwater; however, soils contaminated with greater than 10 percent total explosives by weight pose a potential explosion hazard and should be handled with all the precautions recommended for handling explosives. Such soils usually exhibit visible chunks of explosives. Primary routes of potential exposure of workers to explosives include inhalation or ingestion of contaminated dust, skin absorption from direct contact, and eye exposure from direct contact. EPA Level D personal protective equipment (PPE) is recommended as adequate for typical field activities (National Institute for Occupational Safety and Health (NIOSH) 1985). 


\section{Ease of Operation}

Procedures for site characterization and groundwater monitoring of contamination, hydrology, and geology are standard. Appropriate hardware and analytical laboratories are readily available from commercial suppliers. Analytical methods for the explosives in groundwater are standard U.S. Environmental Protection Agency (USEPA) Method 8330 (USEPA 1994), or slight modifications thereof. Biomarker analyses are not standard procedures, however, and require the use of molecular microbiological tools and radioassays by a sophisticated laboratory. Radioassays require laboratories licensed by the Nuclear Regulatory Commission. Such capabilities are occasionally found commercially, and are usually available at larger universities. Refinements in sampling protocols and sample handling are readily available in Pennington et al. (1999b), and in Pennington et al. (1999a) (see Appendix A, Points of Contact).

\section{Mobilization, Construction, and Operation Requirements}

Mobilization for MNA requires initial site reconnaissance, site conceptualization, development and initiation of a groundwater monitoring plan, and development and initiation of a cone penetrometry sampling event. Construction is limited to installation of any additional monitoring wells or sentinel wells between the contaminant plume and potential receptors of concern. No other physical construction is anticipated. Operations include groundwater and penetrometry sampling for contaminants, hydrogeological and microbiological characterization, and groundwater modeling. Data collection through quarterly sampling is recommended for the first year or two in order to refine sample collection and handling procedures and the site model. Once groundwater hydrology is understood, monitoring frequency can be revised to reflect the anticipated rate of change in contaminant mass or other pertinent site-specific issues related to risk assessment.

\section{E. Key Design Criteria}

No engineering design criteria are associated with MNA. However, criteria for site characterization, monitoring and modeling are described in Pennington et al.1999a. Time frame is an important consideration for MNA, since natural attenuation processes tend to be slow. USEPA (1998) recommends a comparison of estimates of remediation time frames for all appropriate remedy alternatives. This comparison should be included in the feasibility study when a remedial option is selected.

\section{F. Nature and Operation of Monitored Natural Attenuation}

MNA does not require a treatment train, is not capital or operational and maintenance intensive, and produces no treatment residuals (USEPA and U.S. Air Force Environics Directorate 1993). MNA relies upon quality site characterization data, which is also required for implementation of other remedial options; carefully conducted long-term monitoring; and groundwater modeling for contaminant conceptualization and long-term predictions of contaminant fate. Determining attenuation rates for explosives requires demonstration of declining mass over time through collection of groundwater data, and conservative extrapolation of attenuation capacity and microbial degradation potential from the laboratory to the field.

\section{G. Advantage and Strengths of Monitored Natural Attenuation}

The greatest advantage of MNA over engineered remedial alternatives is the potential cost savings. In a cost comparison of MNA with two other technologies, in situ bioremediation and activated carbon adsorption, estimated cost savings using MNA were significant (Pennington, Zakikhani, and Harrelson 1999). MNA also generates less waste, reduces the risk of human and environmental exposure to contaminants during remediation, and is less intrusive than other remedial alternatives. With the possible exception of biomarker technologies, procedures are commercially available, highly reliable, and easily maintained (USEPA and U.S. Air Force Environics Directorate 1993). 


\section{Demonstration Design}

\section{A. Performance Objectives}

\section{Objective in the Demonstration Plan}

Specific objectives of the demonstration were to demonstrate that attenuation of explosives can be determined through appropriate site monitoring, develop guidance for selection of natural attenuation as a remediation alternative, develop guidance for establishing a site monitoring plan and point(s) of compliance, and gain regulatory acceptance of natural attenuation of explosive as a remedial alternative.

\section{Performance Criteria Required for Acceptance of Monitored Natural Attenuation}

The USEPA draft policy directive (USEPA 1998) provides the following criteria for acceptance of MNA. Once site characterization data have been collected and a conceptual model developed, the next step is to evaluate the potential efficacy of MNA as a remedial alternative. This involves collection of site-specific data sufficient to estimate with an acceptable level of confidence both the rate of attenuation processes and the anticipated time required to achieve remediation objectives. A three-tiered approach to such an evaluation is becoming more widely practiced and accepted. In this approach, successively more detailed information is collected as necessary to provide a specified level of confidence on the estimates of attenuation rates and remediation time frame. These three tiers of site-specific information, or "lines of evidence," are as follows:

“(1) Historical groundwater and/or soil chemistry data that demonstrate a clear and meaningful trend $^{[1]}$ of decreasing contaminant mass and/or concentration over time at appropriate monitoring or sampling points. (In the case of a groundwater plume, decreasing concentrations should not be solely the result of plume migration. In the case of inorganic contaminants, the primary attenuating mechanism should also be understood.)

"(2) Hydrogeologic and geochemical data that can be used to demonstrate indirectly the type(s) of natural attenuation processes active at the site, and the rate at which such processes will reduce contaminant concentrations to required levels. For example, characterization data may be used to quantify the rates of contaminant sorption, dilution, or volatilization, or to demonstrate and quantify the rates of biological degradation processes occurring at the site.

“(3) Data from field or microcosm studies (conducted in or with actual contaminated site media) which directly demonstrate the occurrence of a particular natural attenuation process at the site and its ability to degrade the contaminants of concern (typically used to demonstrate biological degradation processes only).

"Unless EPA or the implementing state agency determines that historical data (Number 1 above) are of sufficient quality and duration to support a decision to use MNA, data characterizing the nature and rates of natural attenuation processes at the site (Number 2 above) should be provided. Where the latter are also inadequate or inconclusive, data from microcosm studies (Number 3 above) may also be necessary. In general, more supporting information may be required to demonstrate the efficacy of MNA at those sites with contaminants which do not readily degrade through biological processes (e.g., most non-petroleum compounds, inorganics), at sites with contaminants that transform into more toxic and/or mobile forms than the parent contaminant, or at sites where monitoring has been

1 For guidance on statistical analysis of environmental data, please see USEPA 1989, 1993a, 1993b; and Gilbert 1987 , listed in the "General References" section at the end of this report. 
performed for a relatively short period of time. The amount and type of information needed for such a demonstration will depend upon a number of site-specific factors, such as the size and nature of the contamination problem, the proximity of receptors and the potential risk to those receptors, and other physical characteristics of the environmental setting (e.g., hydrogeology, ground cover, climatic conditions)."

\section{Performance Metrics from the Demonstration Plan}

The technical performance criteria established in the demonstration plan included the following:

- Decreases in concentrations of TNT and RDX below concentrations predicted from the site geology and hydrology. These results will suggest that the explosives are attenuated in the subsurface by degradation, transformation, and/or immobilization processes.

- Increases in concentrations of transformation/degradation products of TNT and RDX. These results will demonstrate formation of known transformation and/or degradation products. Spatial distribution of these products relative to parent compounds and uncontaminated area can be used to assess the progression of degradation mechanisms. Some intermediates are considered environmentally undesirable; therefore, these intermediates must be tracked as carefully as the parent compounds. The amino substituted transformation products of TNT are much more subject to immobilization processes than the parent compound; therefore, their appearance and disappearance are also important to track.

- Predictions by the model that potential receptors will be protected due to documented site geological and hydrological characteristics. The groundwater flow rate and subsurface permeability may be so low that receptors are protected for a significantly long time. Site data together with application of a model will reveal the potential for acceptable risk.

\section{B. Physical Setup and Operation}

Before the demonstration, tests were conducted to optimize the reliability of the monitoring data. Tests were conducted (1) to define the relationship between concentrations of explosives, dissolved oxygen (DO), and volume of water extracted, and (2) to optimize the preservation of analytes for chemical analyses. Results of the first tests revealed a general inverse relationship between explosives concentration and DO (Figure 1). No significant difference between removal of three well volumes and the volume extracted when DO became stable was found. Therefore, for the Louisiana Army Ammunition Plant, Minden, LA (LAAP), either bailing of

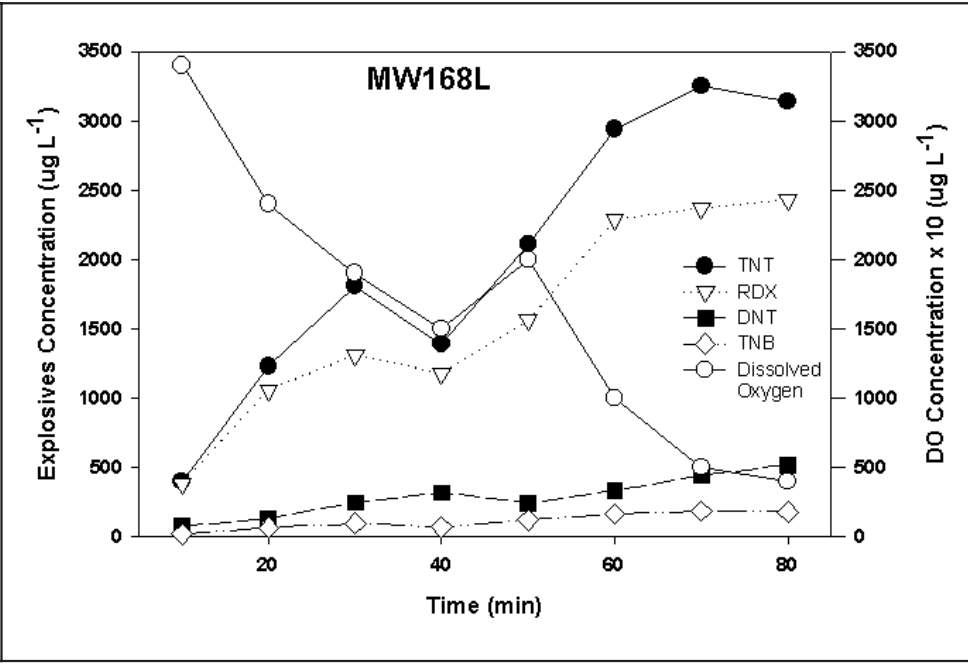

Figure 1. Relationship between DO and explosives concentration. three well volumes or pumping until stable DO was achieved was acceptable. Results of preservatives tests indicated that sodium bisulfate was better than mercuric chloride or no preservation.

Monitoring frequency should be based upon known attenuation rates at the site. If the rate cannot be estimated from historical groundwater data, quarterly sampling for the first year or two should provide sufficient data to refine the monitoring plan. The following approach was employed at the LAAP site: 
1. Well monitoring: Wells were sampled quarterly for 2 years. Approximately 5 hours was originally needed to sample one well and move to the next. However, sampling time was greatly compressed to about 3 hours when two 2-man crews operated in "leap-frog" fashion; i.e., while one crew monitored and demobilized at one well, the other crew set up and initiated monitoring at the next well.

2. Cone penetrometry: One sampling event was conducted at the LAAP. The time required for a sampling depends upon the size of the area under examination and the extent of data required. During a typical day without complications, eight penetrations to a depth of 15 to $40 \mathrm{~m}$ may be completed. At LAAP, 51 penetrations to a maximum depth of $40 \mathrm{~m}$ were executed in 15 days with a 4-man crew operating the truck and performing decontamination of equipment between penetrations, and a 3-man crew processing samples for microbial and chemical analyses.

3. Analytical chemistry: Samples must be processed within 7 days. Six to seven days are required to analyze samples from one sampling event: 1 day to process, 2 days to extract, and 3-4 days for analysis, data reporting, etc.

4. Radioassay: Analysis requires approximately 48 days (approximately 10 days for acetate mineralization; 28 days for RDX and TNT mineralization; 14 days for liquid phase separation, solid phase burning, breakdown, and data preparation). Total time required is 2 to 2.5 months, depending on the number of samples collected at the site.

5. Lipid biomarker analysis: Sets of 8-12 samples can be processed in a 3-day period.

6. Nucleic acid analysis: One person can process eight samples in a 3-day period.

7. Statistical analyses: One statistician for 0.33 man-year was employed over the 2-year monitoring period.

\section{Monitoring Procedures}

Monitoring well samples were collected using a micropurge sampling technique described in Pennington et al. (1999b). Wells were sampled in order from least to greatest contaminant concentration based on existing data to minimize the potential for cross contamination. Cone penetrometry samples were collected along transects that bisected the plume from highest to lowest contaminant concentrations in four directions and vertically. Soil samples were collected using a split spoon sampler according to procedures described in Pennington et al. (1999b). A field test kit was used to determine the concentration of explosives immediately after sample collection. These analyses guided the placement of the next penetration to minimize the cost of taking data outside the plume. Data precision, accuracy, representativeness, and comparability were assured by adopting field and laboratory quality control and quality assurance procedures as described in Pennington et al. (1999b). Standard operating procedures are presented in Pennington et al. (unpublished) and appended to Pennington et al. (1999a). (See Appendix A, Points of Contact, and Appendix B, Data Archiving and Demonstration Plan.)

\section{Analytical Procedures}

\section{Explosives and Their Degradation Products}

Groundwater from quarterly monitoring and soils collected by cone penetrometry (CPT) were analyzed by High Performance Liquid Chromatography (HPLC) using modifications of Method 8330 (USEPA 1994). The modifications included expanding the analyte list and adoption of an extraction technique for soils (Pennington et al. 1999b). Analytes for groundwater and soils are listed in Table 1 for LAAP and Joliet Army Ammunition Plant, Joliet, IL (JAAP). 
Table 1

Explosives and Related Analytes Monitored in Groundwater at LAAP and JAAP

\begin{tabular}{||l|l||}
\hline \hline Chemical Name & Acronym \\
\hline \hline 2,4,6-Trinitrotoluene & TNT \\
1,3,5-Trinitro-1,3,5-hexahydrotriazine & RDX \\
Octahydro-1,3,5,7-tetranitro-1,3,5,7-tetrazocine & HMX \\
N,2,4,6-Tetranitro-N-methylaniline & Tetryl \\
1,3,5-Trinitrobenzene & TNB \\
2,6-Dinitrotoluene & 2,6 DNT \\
2,4-Dinitrotoluene & 2,4 DNT \\
1,3-Dinitrobenzene & 1,3DNB \\
Nitrobenzene & NB \\
4-Amino-2,6-dinitrotoluene & 4ADNT \\
2-Amino-4,6-dinitrotoluene & 2ADNT \\
3,5-Dinitroanaline & 35DNA \\
2,4-Diamino-6-nitrotoluene & 24DANT \\
2,6-Diamino-4-nitrotoluene & 26DANT \\
2,2',4,4'-Tetranitro-6,6'-azoxytoluene & 66'AZOXY \\
4,4',6,6'-Tetranitro-2,2'-azoxytoluene & 22'AZOXY \\
2,2',6,6'-Tetranitro-4,4'-azoxytoluene & 44'AZOXY \\
Hexahydro-1-nitroso-3,5-dinitro-1,3,5-triazine & MNX \\
Hexahydro-1,3-dinitroso-5-dinitro-1,3,5-triazine & DNX \\
Hexahydro-1,3,5-trinitroso-1,3,5-triazine & TNX \\
Mononitroso-octahydro-1,3,5,7-tetranitro-1,3,5,7-tetrazocine & MN-HMX \\
Picric acid & \\
\hline
\end{tabular}

\section{Geochemical Parameters}

The geochemical parameters determined on groundwater samples are given in Table 2. Methods are given in Pennington et al. (1999b).

Soil samples were analyzed for explosives (Table 1), particle size distribution, hydraulic conductivity,

\section{Table 2}

Geochemical Parameters Monitored in Groundwater at LAAP and JAAP

\begin{tabular}{|l|l|l||}
\hline \multirow{2}{*}{ Monitored in the Field } & \multicolumn{2}{|c||}{ Assayed in the Laboratory } \\
\cline { 2 - 3 } & Aerobic Collection & Anaerobic Collection \\
\hline \hline $\mathrm{pH}$ & Total organic carbon & Reduced iron \\
$\mathrm{Conductivity}$ & Total iron & Methane \\
DO & Calcium & \\
Temperature & Magnesium & \\
Redox potential & Manganese & \\
Turbidity & Nitrate/nitrite nitrogen & \\
Salinity & Sulfate & \\
& Chloride & \\
\hline
\end{tabular}

$\mathrm{pH}$, nitrate/nitrite nitrogen, total Kjeldahl nitrogen, phosphorus, sulfate, and total organic carbon as described in Pennington et al. (1999b).

\section{Other Analyses}

Groundwater, surface soils, and subsurface soils were tested for explosives mineralization potential, and the presence of lipid and nucleic acid biomarkers. Procedures are described in Pennington et al.

(1999b). 
Site capacity was determined by batch partitioning tests according to procedures in 40CFR796.2750 (retrieve at http://www.access.gpo.gov/nara/cfr/cfr-retrieve.html\#page 1, Sediment and soil adsorption isotherm) and presented in Pennington et al. 1999a and 1999b).

Trend analysis was used to determine whether groundwater concentrations of any explosive, including transformation and degradation products, were significantly increasing or decreasing over time. The trend analysis consisted of normality testing, regression analyses, lack-of-fit analyses, and rank correlation analyses (Pennington et al. 1999b). Masses of contaminants (TNT and RDX) were calculated using both measured and predicted concentrations along with iso-surface volume calculations from the Department of Defense Groundwater Modeling System (Engineering Computer Graphic Laboratory 1998) (see Pennington et al. 1999b).

\section{E. Demonstration Site}

\section{Facility Background}

The LAAP was selected because the source of contamination had already been remediated, a large body of contaminant data was available (Science Applications International Corporation 1994), and the site was well-characterized with approximately 50 functional groundwater monitoring wells in place. The demonstration was conducted at Area P (Figure 2), the site where wastes from loading, assembling, and packing of munitions (Standard Industrial Classification Code: 2892, chemical and allied products, explosives, Member Agencies of the Federal Remediation Technologies Roundtable 1995) had been disposed

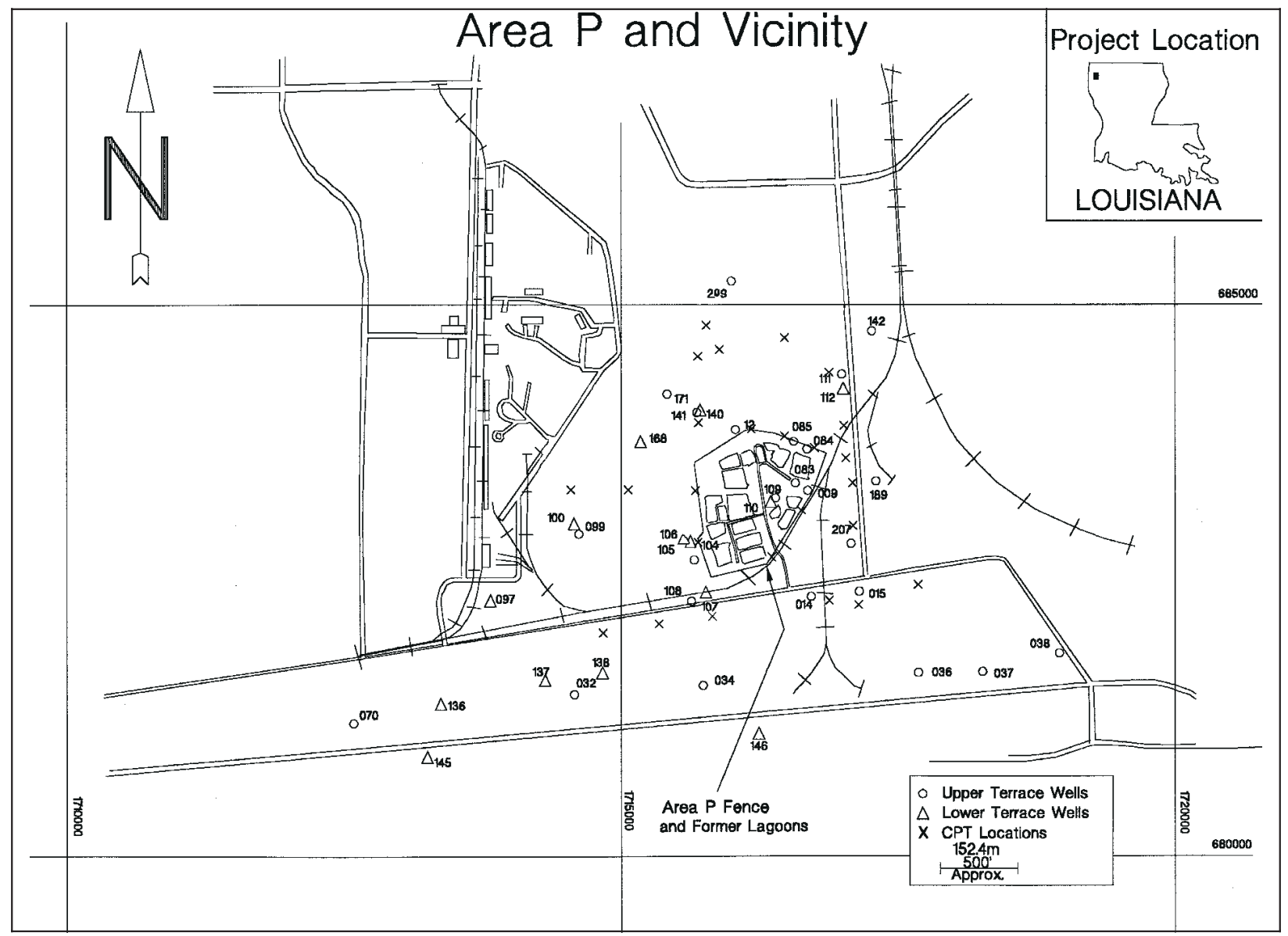

Figure 2. Area P at LAAP showing former lagoons, capped area, monitoring wells, and CPT locations. 
into 16 unlined lagoons. The lagoons had been pumped out and the sediment excavated and incinerated in the late 1980s. The area was capped with clay compacted to 90 percent of the standard proctor density for the clay used. The cap was covered with 4 inches of topsoil with a slope of at least 1 percent to facilitate drainage. No formal approvals, licenses, or permits were required prior to conducting the demonstration.

\section{Facility Characteristics}

The near-surface geology at LAAP has a complex stratigraphy of Pleistocene, terraced fluvial deposits (basal gravels fining upward to clays) unconformably overlying Eocene, nonmarine, massive sands, silty sands, silty clays, and occasional lignitic beds. An effectively impermeable boundary, the Cane River Formation, lies below the fluvial deposits. Matrix characteristics of this site that potentially affect attenuation include the following: clay lenses, silts, and low porosity, which can promote immobilization processes for transformation products of TNT and effectively reduce groundwater flow rates; and low organic carbon in aquifer soils, which decreases the likelihood for immobilization by interactions of TNT transformation products with organic carbon and also decreases microbial degradation potential because of limited co-substrate.

Data from the late 1980s indicated that the explosives contaminants from the Area P lagoons had entered the terrace aquifers. Groundwater plumes containing RDX, TNT, and TNB had been detected in exceedance of drinking water Health Advisory Levels (Science Applications International Corporation 1994). Concentrations detected in the upper terrace aquifer in 1994 were lower than concentrations detected in 1990, indicating an improvement in the groundwater quality at Area P since the removal of the lagoons. The groundwater contaminant plumes had not advanced very far laterally, suggesting either attenuation or very slow transport. Conceptualization of the lateral extent of the TNT contaminant plume in the upper terrace aquifer at the inception of the study (February 1996) and the predicted reduction over 20 years are illustrated in Figure 3. Reductions in the extent of the RDX plume predicted over time are illustrated in Figure 4.

\section{Performance Assessment}

\section{A. Significant Deviations from Demonstration Plan}

The following modifications were made to the sampling plan set forth in the demonstration plan (Pennington et al. unpublished): (1) refinements in the procedure used to clear the wellhead of oxidized water prior to sampling; and (2) a reduction in the number of wells routinely monitored. In the first case, if DO stabilized, the procedure outlined in the demonstration plan was used. If the DO did not stabilize, three well volumes were removed by pumping before the sample was collected. In the second case, the demonstration plan called for sampling 30 wells during each sampling event. However, contaminant concentration levels in many wells were below detection limits. Therefore, these wells were sampled only once per year to verify that concentrations remained below detection.

\section{B. Data Assessment}

Trends in contaminant concentrations over the 2-year study period were analyzed statistically for the 11 wells in which most analytes were consistently detected. Significant declines in contaminant concentrations occurred in 9 of the 11 wells over the 2-year study period (Figure 5). Contaminant mass calculations also indicated declining mass from 52 and 78 to 50 and 68 metric tons for TNT and RDX, respectively.

\section{Field Observations and Comparison to Technology Claims}

The monitoring well sampling procedures and modifications made during the course of the demonstration project performed well. The monitoring protocol required no further modifications when applied to a 

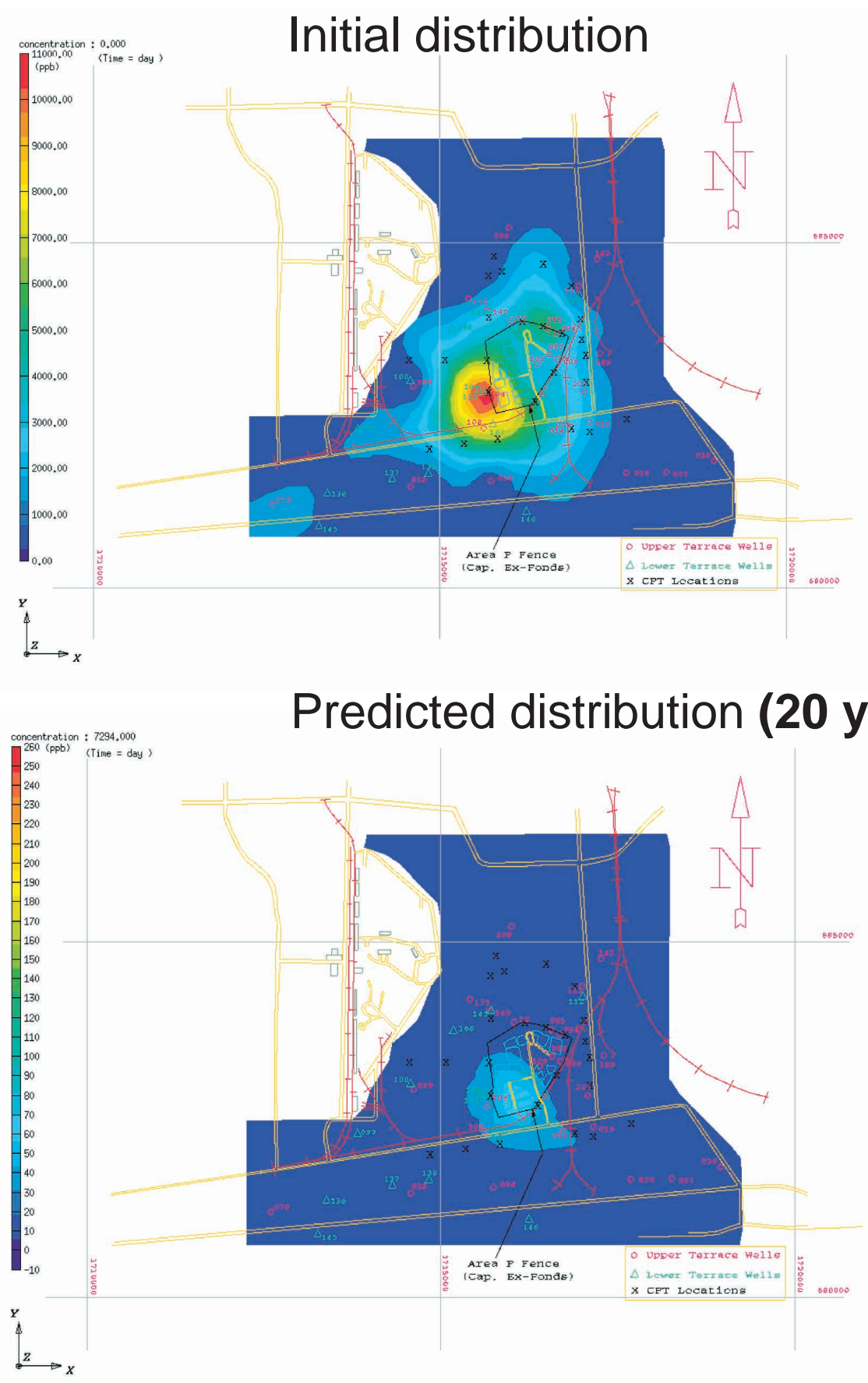

Figure 3. Conceptualization of the lateral extent of the TNT contaminant plume in the upper terrace aquifer at the inception of the study (February 1996) and the predicted reduction over 20 years

second site at JAAP (Pennington et al. 1998). The cone penetrometry sampling protocols also applied well to JAAP. Biomarker results for JAAP surface soils, which exhibited higher contaminant concentrations than soils examined at LAAP (the surface soil source at JAAP had not yet been remediated), indicated the effectiveness of the techniques for determining site potential for attenuation of TNT and RDX. The modeling procedures were effective at both sites. 

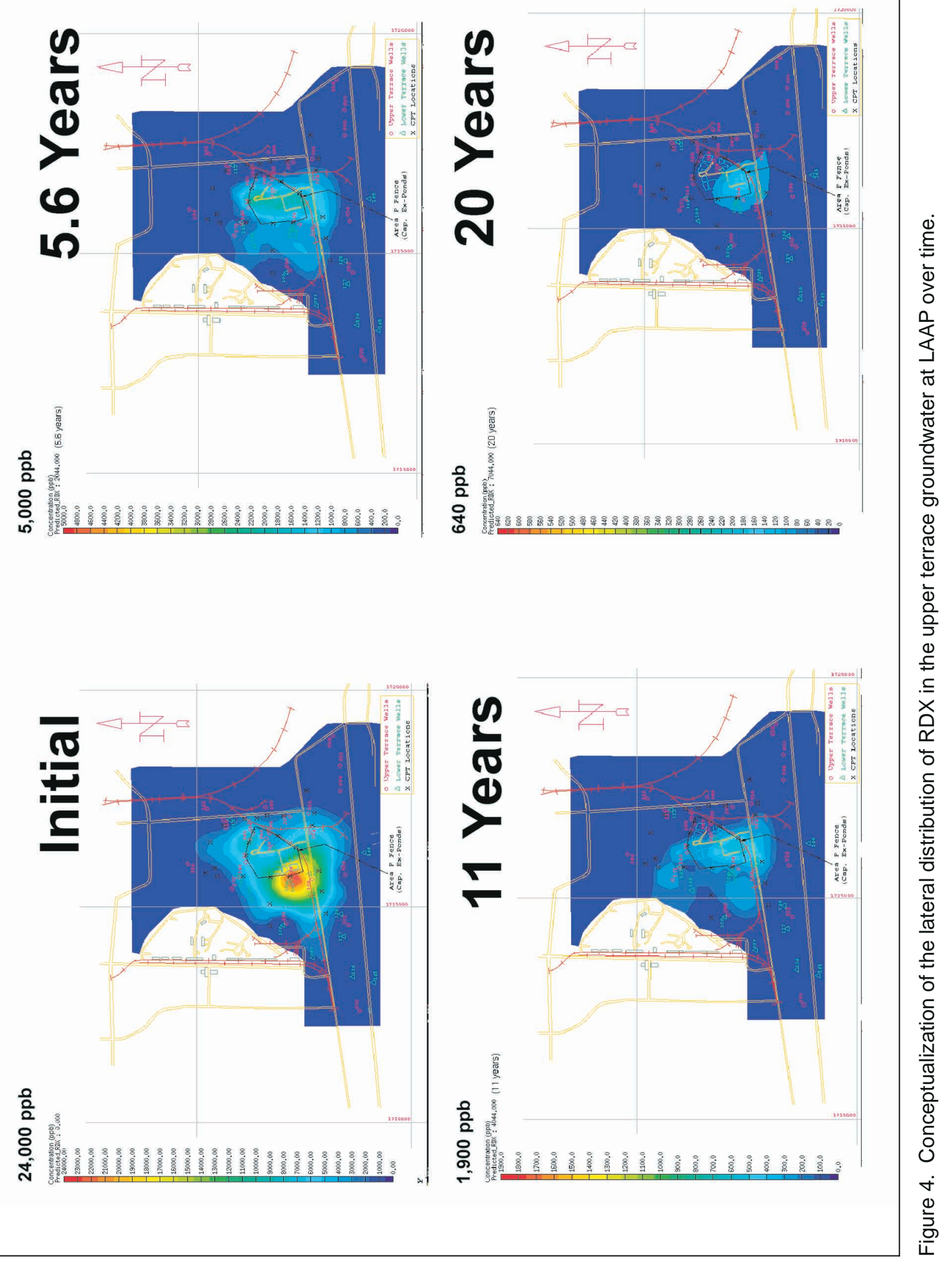
Personnel and training were adequate. The demonstration plan called for the use of Modified Level C PPE. This was later reduced to Level D and consisted of steel-toed shoes and safety goggles. Latex gloves were also required due to irritants in the groundwater at several wells.

Groundwater monitoring procedures were easy to execute. Efficiency was improved by using two 2-man field crews. Execution of biomarker analyses is not yet a standard, "offthe-shelf" technology; however, commercially available capabilities are anticipated to develop rapidly for various applications over the next several years. Most large universities already have the necessary capabilities. Existing groundwater models are readily adapted to use in MNA (see lists of models in Pennington et al. 1999a).

The current state of the science allows for indirect determinations of subsurface attenuation processes via contaminant concentration monitoring and measurements of site capacity and microbial degradation potential. Therefore, a weight of evidence is required to demonstrate that natural attenuation is sufficient to meet remediation goals. Time to complete cleanup may be longer than with

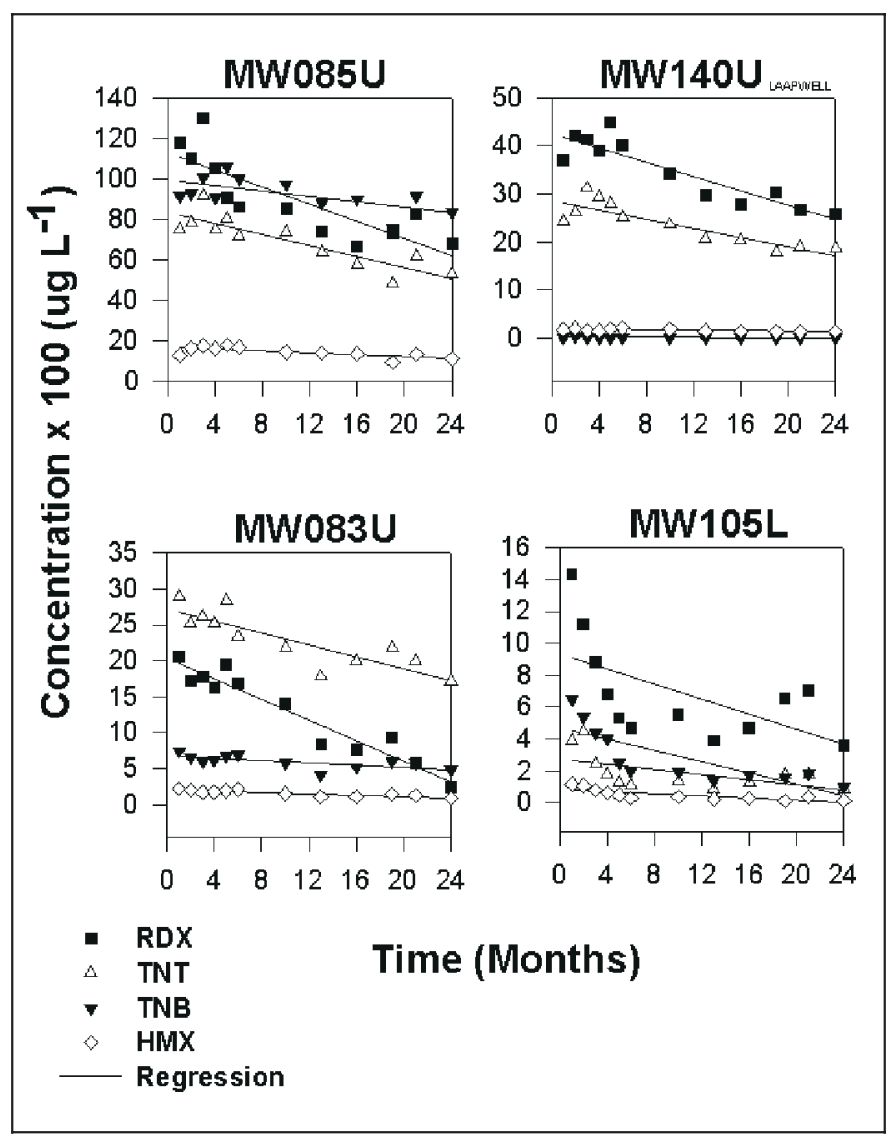

Figure 5. Trends in explosives concentrations in selected monitoring wells over the 2-year sampling period at LAAP

other remedial options. Awareness of the potential for MNA as a remedial alternative is growing, but regulatory and community acceptability may be limited.

\section{Overall Conclusions}

The trend analysis of groundwater data and the reduction in contaminant mass demonstrated that natural attenuation is occurring at LAAP. Site capacity and biomarker techniques contributed to a weight of evidence by estimating process rates. Numerical models predict significant continuing reductions in contaminant masses of TNT and RDX over 20 years (Figure 3 shows initial and predicted lateral extent of the TNT plume at LAAP). The demonstration project showed that the effectiveness of MNA can be determined by observation of declining contaminant mass over time through a carefully conducted long-term monitoring plan and conservative extrapolation of attenuation capacity and microbial degradation potential from the laboratory to the field.

\section{Cost Assessment}

\section{A. Treatment Costs for the Demonstration}

Treatment costs associated with the LAAP natural attenuation demonstration project amounted to approximately $\$ 4$ million. These costs consisted of refinements in site characterization, site monitoring, modeling, and development of biomarker techniques. Although extensive site characterization had been performed previously at LAAP, additional hydrogeologic and microbiological data were acquired. Site 
characterization costs, including the cone penetrometry for characterization, site capacity determinations, and biomarker analyses, were approximately $\$ 2.5$ million. The principal costs were for labor (approximately $\$ 2$ million) and chemical analyses (approximately $\$ 0.5$ million).

\section{B. Scale-up Considerations}

The LAAP demonstration project was a full, field-scale demonstration encompassing the whole contaminant plume and its potential receptors. However, implementation costs will be lower than demonstration project costs for three reasons. First, procedures for microbiological analyses were developed and refined during the demonstration. Costs for future implementation of these procedures will be significantly less. Second, costs of monitoring will be lower because experiments for refining monitoring techniques were part of demonstration costs, but will not be part of implementation costs. Third, improved sampling procedures significantly lowered the length of time required for a single sampling event. Cost estimates for full implementation of MNA prepared according to the guidelines for work breakdown structure (Headquarters, U.S. Army Corps of Engineers 1996) and using cost estimates prepared by Environmental Cost Handling Options and Solution (ECHOS 1998a, 1998b) are presented in Pennington, Zakikhani, and Harrelson (1999). That document also contains cost and performance comparisons with two other remediation technologies.

\section{Implementation Issues}

\section{A. Cost Observations}

Since many aspects of the demonstration included significant experimentation, costs associated with implementation at another site are expected to be lower. The cost differences between demonstration and implementation are due to improved familiarity with the technology. Lessons learned during the demonstration project resulted in greater labor and cost efficiencies in the areas of groundwater sampling and microbiological analysis. In the case of groundwater sampling, modifications that improved sampling procedures and the incorporation of fallback procedures led to greater labor efficiencies. These efficiencies led to savings when LAAP groundwater sampling procedures were applied to JAAP. For microbiological analyses, improved analytical procedures, e.g., adaptation to microtiter plate scale of operations, significantly lowered analytical costs, with costs falling over the course of the project from $\$ 1,250.00$ to $\$ 600.00$ and from $\$ 530.00$ to $\$ 344.00$ for radioassays and lipid biomarker analyses, respectively.

Factors that will influence costs in the future implementation of MNA are the suitability of existing site characterization data, the size and concentrations of the contaminant plume, site hydrogeology, and the method used for investigation-derived wastes disposal. These are discussed in Pennington, Zakikhani, and Harrelson (1999).

\section{B. Performance Observations}

Periodic reassessment, e.g., every 5 years depending upon site-specific conditions, will be necessary to assure that MNA is protective of human health and the environment. At that time the monitoring plan should be reviewed and any revisions made, groundwater models should be updated, and contingency plans reviewed in light of changing site conditions and developing technologies that may be suitable replacements for the contingencies selected earlier.

\section{Regulatory and Other Issues}

Regulatory issues will be site-specific. However, the USEPA (1998) draft directive is a useful guide. Early involvement of the regulatory community and other interested parties will contribute to acceptance. 


\section{Lessons Learned}

An important lesson learned from the demonstration project is that the sampling protocol must be specific and followed consistently to generate data that are adequate for measuring trends in contaminant mass over time. The influence of oxygenated water at the wellhead on explosives concentration data has been demonstrated at LAAP. Pumping with a low-flow pump to match removal rates to recharge rates minimizing the influence of removal on the contaminant plume and removing at least three well volumes before collection of the groundwater sample contribute to reliability of data.

Cone penetrometry was a useful activity for refining the conceptualization of the site hydrogeology and contaminant distribution and provided subsurface sample material for biomarker analyses. Another important lesson learned was the importance of discourse between personnel generating data and personnel generating the model. For example, data must be translated into units of measure suitable for incorporation into the model. The scale of measurement actually taken and those needed for modeling often differ significantly.

\section{References}

\section{Key References}

Engineering Computer Graphic Laboratory. (1998). "Department of Defense Groundwater Modeling System, GMS v2.1, Reference Manual,” Brigham Young University, Provo, UT.

Environmental Cost Handling Options and Solutions (ECHOS). (1998a). "Environmental restoration: Assemblies cost data," Delta Technologies Group, Inc., ed., $4^{\text {th }}$ ed., R. S. Means Company, Inc., and Delta Technologies Group, Inc., Englewood, CO.

Environmental Cost Handling Options and Solutions (ECHOS). (1998b). "Environmental restoration: Unit cost data," Delta Technologies Group, Inc., ed., $4^{\text {th }}$ ed., R. S. Means Company, Inc., and Delta Technologies Group, Inc., Englewood, CO.

Headquarters, U.S. Army Corps of Engineers. (1996 (15 Nov)). “Technical requirements for specifications to report HTRW Environmental restoration cost and performance,” Engineer Pamphlet EP 1110-1-19, Washington, DC.

Member Agencies of the Federal Remediation Technologies Roundtable. (1995). "Guide to documenting cost and performance for remediation projects,” EPA-542-B-95-002, U.S. Environmental Protection Agency, Washington, DC.

U.S. Environmental Protection Agency. (1998). "Use of monitored natural attenuation at Superfund, RCRA corrective action, and underground storage tank sites," Interim final directive, Office of Solid Waste and Emergency Response Directive 9200.4-17, Washington, DC.

U.S. Environmental Protection Agency and U.S. Air Force Environics Directorate. (1993). "Remediation technologies screening matrix and reference guide," Version 1, joint U.S. Environmental Protection Agency, Office of Solid Waste and Emergency Response, Technology Innovation Office, Washington, DC, and the U.S. Air Force Environics Directorate, Armstrong Laboratory, Tyndall Air Force Base, FL.

\section{General References}

Gilbert, R. O. (1987). Statistical methods for environmental pollution monitoring. Van Nostrand Reinhold, New York.

National Institute for Occupational Safety and Health. (1985). "Occupational safety and health guidance manual for hazardous waste site activities," NIOSH Publication No. 85-115, National Institute for Occupational Safety and Health, Occupational Safety and Health Administration, U.S. Coast Guard, U.S. Environmental Protection Agency, U.S. Government Printing Office, Washington, DC.

Pennington, J. C., Zakikhani, M., and Harrelson, D. W. (1999). "Monitored natural attenuation of explosives in groundwater Environmental Security Technology Certification Program completion report,” Technical Report EL-99-7, U.S. Army Engineer Waterways Experiment Station, Vicksburg, MS.

Pennington, J. C., Harrelson, D. W., Zakikhani, M., Gunnison, D., Hayes, C. A., Clarke, J. U., Perkins, E., Ringelberg, D., McGrath, C. J., Fredrickson, H., and May, J. H. (1998). "Feasibility of using monitored natural attenuation as a remedial alternative for explosives-contaminated groundwater at Site L1, Joliet Army Ammunition Plant, Joliet, Illinois," Technical Report EL-98-8, U. S. Army Engineer Waterways Experiment Station, Vicksburg, MS. 
Pennington, J. C., Bowen, R., Brannon, J. M., Gunnison, D., Harrelson, D. W., Zakikhani, M., Clarke, J., Mahannah, J., and Gnewuch, S. (1999a). "Draft protocol for evaluating, selecting and implementing monitored natural attenuation at explosivescontaminated sites" (in preparation ), U.S. Army Engineer Waterways Experiment Station, Vicksburg, MS.

Pennington, J. C., Gunnison, D., Harrelson, D. W., Brannon, J. M., Zakikhani, M., Jenkins, T. F., Clarke, J. U., Hayes, C. A., Myers, T., Perkins, E., Ringleberg, D., Townsend, D., Fredrickson, H., May, J. H. (1999b). "Monitored natural attenuation of explosives in soil and water systems at DoD sites: Interim Report," Technical Report EL-99-8, U.S. Army Engineer Waterways Experiment Station, Vicksburg, MS.

Pennington, J. C., McCartney, S., May, I., Haines, L., Harrelson, D. W., and May, T. H. (unpublished). "Natural attenuation of explosives in groundwater: Technology demonstration plan," U.S. Army Engineer Waterways Experiment Station, Vicksburg, MS.

Science Applications International Corporation. (1994). "Five-year review report of interim remedial action at former Area P lagoons, Louisiana Army Ammunition Plant, Shreveport, LA," Prepared for U.S. Army Toxic and Hazardous Materials Agency under Contract No. DAAA15-91-D0017, by Science Applications International Corporation, McLean, VA.

U. S. Environmental Protection Agency. (1989). "Methods for evaluation attainment of cleanup standards; Vol. 1: Soils and solid media," EPA/230/02-89-042, Office of Solid Waste, Washington, DC.

U. S. Environmental Protection Agency. (1993a). "Guidance document on the statistical analysis of ground-water monitoring data at RCRA facilities," Office of Solid Waste, Washington, DC.

U. S. Environmental Protection Agency. (1993b). "Methods for evaluation attainment of cleanup standards; Vol. 2: Ground Water," EPA/230/R-92/014, Office of Policy, Planning, and Evaluation, Washington, DC.

U. S. Environmental Protection Agency. (1994). "Nitroaromatic and nitramines by HPLC," $2^{\text {nd }}$ update, SW846, Method 8330, Office of Solid Waste and Emergency Response, Washington, DC. 


\section{Appendix A Points of Contact}

Dr. Judith C. Pennington

Principal Investigator

U.S. Army Engineer Waterways

Experiment Station

3909 Halls Ferry Road

Vicksburg, MS 39180-6199

601-634-2802

FAX: 601-634-3410

E-mail: penninj@ex1.wes.army.mil

Dr. James M. Brannon

Principal Project Geochemist

U.S. Army Engineer Waterways

Experiment Station

3909 Halls Ferry Road

Vicksburg, MS 39180-6199

601-634-3873

FAX: 601-634-4017

E-mail: brannoj@ex1.wes.army.mil

Dr. Joan U. Clarke

Project Statistician

U.S. Army Engineer Waterways

Experiment Station

3909 Halls Ferry Road

Vicksburg, MS 39180-6199

601-634-2954

FAX: 601-634-3120

E-mail: clarkej@ex1.wes.army.mil

Ms. Laurie Haines

LAAP Site Geologist

U. S. Army Environmental Center

ATTN: SFIM-AEC-IR-G

BLDG E4435

Aberdeen Proving Ground, MD

410-671-1512

FAX 410-671-1548

E-mail: lbhaines@aec.apgea.army.mil

Mr. Art Holz

Environmental Coordinator

Joliet Army Ammunition Plant

29401 South, Route 53

Wilmington, IL 60481-8879

815-423-2877

E-mail: aholz@ria-emh2.army.mil
Dr. Douglas Gunnison

Principal Project Microbiologist

U.S. Army Engineer Waterways

Experiment Station

3909 Halls Ferry Road

Vicksburg, MS 39180-6199

601-634-3873

FAX: 601-634-4017

E-mail: gunnisd@ex1.wes.army.mil

Dr. Mansour Zakikhani

Principal Project Groundwater Modeler

U.S. Army Engineer Waterways

Experiment Station

3909 Halls Ferry Road

Vicksburg, MS 39180-6199

601-634-3806

FAX: 601-634-3129

E-mail: zakikhm@ex1.wes.army.mil

Drs. Mike Reynolds and Paul Miyares

Stable Isotopes

U.S. Army Cold Regions Research

and Engineering Laboratory

72 Lyme Road

Hanover, NH 03755-1290

603-646-4394; 603-646-4734

FAX: 603-646-4561

E-mail: reynolds@crrel.usace.army.mil miyares@crrel.usace.army.mil

Mr. Doyle Williams

Environmental Officer

Louisiana Army Ammunition Plant

Hwy 80

Minden, LA 71055

318-459-5108

FAX 318-459-5114

Dr. Rick Bowen

Arthur D. Little, Inc.

Acorn Park

Cambridge, MA 02140-2390

617-498-5406

FAX 617-498-7221

E-mail: bowen.r@adlittle.com
Mr. Danny W. Harrelson

Principal Project Geologist

U.S. Army Engineer Waterways

Experiment Station

3909 Halls Ferry Road

Vicksburg, MS 39180-6199

601-634-2685

FAX: 601-634-3153

E-mail: harreld@ex1.wes.army.mil

Dr. Thomas F. Jenkin

Principal Project Analytical

Chemist

U.S. Army Cold Regions Research

and Engineering Laboratory

72 Lyme Road

Hanover, NH 03755-1290

603-646-4385

FAX: 603-646-4785

E-mail: tjenkins@crrel.usace.army.mil

Mr. Cyril Onewokae

Validation Site Sponsor

Environmental Quality Directorate

HDQ, Industrial Operations Command

BLDG 390

Rock Island, IL 61299-6000

309-782-1350

FAX: 309-782-1457

E-mail: conewoka@ riaemh2.army.mil

Ms. Diana Mally

U.S. Environmental Protection

Agency, Region V

ATTN: SRF-5J

77 West Jackson Boulevard

Chicago, IL 60604-7275

312-886-7275

Ms. Caroline Ziegler

1445 Ross Avenue, Suite 1200

U.S. Environmental Protection Agency

Region VI

Dallas, TX 75202

214-665-2178 


\title{
Appendix B \\ Data Archiving and Demonstration Plan
}

Requests concerning data from the Louisiana Army Ammunition Plant should be addressed to

Dr. Judith C. Pennington, CEWES-ES-P

U.S. Army Engineer Waterways Experiment Station

3909 Halls Ferry Road

Vicksburg, MS 39180-6199

601-634-2802

penninj@ex1.wes.army.mil

Requests concerning the project demonstration plan and standard operational procedures for the field efforts should be addressed to

\author{
Mr. Danny Harrelson, CEWES-GG-YG \\ U.S. Army Engineer Waterways Experiment Station \\ 3909 Halls Ferry Road \\ Vicksburg, MS 39180-6199 \\ 601-634-2685 \\ harreld@ex1.wes.army.mil
}

Requests concerning groundwater modeling should be addressed to

Dr. Mansour Zakikhani, CEWES-ES-Q

U.S. Army Engineer Waterways Experiment Station

3909 Halls Ferry Road

Vicksburg, MS 39180-6199

601-634-3806

zakikhm@ex1.wes.army.mil

The following technical reports concerning the project are available by e-mail request from any of the above contacts or from Ms. Betty Walker at walker@ex1.wes.army.mil:

Pennington, J. C., Zakikhani, M., and Harrelson, D. W. (1999). "Monitored natural attenuation of explosives in groundwater ESTCP completion report,” Technical Report EL-99- , U.S. Army Engineer Waterways Experiment Station, Vicksburg, MS.

Pennington, J. C., Harrelson, D. W., Zakikhani, M., Gunnison, D., Hayes, C. A., Clarke, J. U., Perkins, E., Ringelberg, D., McGrath, C. J., Fredrickson, H., and May, J. H. (1998). "Feasibility of using monitored natural attenuation as a remedial alternative for explosives-contaminated groundwater at Site L1, Joliet Army Ammunition Plant, Joliet, Illinois," Technical Report EL-98-8, U.S. Army Engineer Waterways Experiment Station, Vicksburg, MS.

Pennington, J. C., Bowen, R., Brannon, J. M., Gunnison, D., Harrelson, D. W., Zakikhani, M., Clarke, J., Mahannah, J., and Gnewuch, S. (1999). "Draft protocol for evaluating, selecting and implementing monitored natural attenuation at explosivescontaminated sites,” Technical Report EL-99-x , U.S. Army Engineer Waterways Experiment Station, Vicksburg, MS.

Pennington, J. C., Gunnison, D., Harrelson, D. W., Brannon, J. M., Zakikhani, M., Jenkins, T. F., Clarke, J. U., Hayes, C. A., Myers, T., Perkins, E., Ringleberg, D., Townsend, D., Fredrickson, H., May, J. H. (1999). "Monitored natural attenuation of explosives in soil and water systems at DoD sites: Interim Report," Technical Report EL-99-x , U.S. Army Engineer Waterways Experiment Station, Vicksburg, MS.

Pennington, J. C., McCartney, S., May, I., Haines, L., Harrelson, D. W., and May, T. H. (unpublished). "Natural attenuation of explosives in groundwater - Technology demonstration plan," U.S. Army Engineer Waterways Experiment Station, Vicksburg, MS. 


\section{List of Acronyms}

CPT

DO

ESTCP

HPLC

JAAP

LAAP

MNA

PPE

RDX

TNT

USEPA
Cone penetrometry

Dissolved oxygen

Environmental Security Technology Certification Program

High Performance Liquid Chromatography

Joliet Army Ammunition Plant

Louisiana Army Ammunition Plant

Monitored Natural Attenuation

Personal Protective Equipment

1,3,5-Trinitro-1,3,5-hexahydrotriazine

2,4,6-Trinitrotoluene

U.S. Environmental Protection Agency 


\section{REPORT DOCUMENTATION PAGE}


the data needed, and completing and reviewing the collection of information. Send comments regarding this burden estimate or any other aspect of this collection of information, including suggestions for reducing this burden, to Washington Headquarters Services, Directorate for Information Operations and Reports, 1215 Jefferson Davis Highway, Suite 1204, Arlington, VA22202-4302, and to the Office of Management and Budget, Paperwork Reduction Project (0704-0188), Washington, DC20503.

\begin{tabular}{|l|l|l|}
\hline 1. AGENCY USE ONLY (Leave blank) & 2. $\begin{array}{l}\text { REPORT DATE } \\
\text { April } 1999\end{array}$ & $\begin{array}{l}\text { 3. } \\
\text { REPORT TYPE AND DATES COVERED } \\
\text { Final report }\end{array}$
\end{tabular}

\section{TITLE AND SUBTITLE}

Monitored Natural Attenuation of Explosives in Groundwater: Cost and Performance

\section{FUNDING NUMBERS}

6. AUTHOR(S)

Judith C. Pennington, Mansour Zakikhani, Danny W. Harrelson, Daniel S. Allen

\section{PERFORMING ORGANIZATION NAME(S) AND ADDRESS(ES)}

U.S. Army Engineer Waterways Experiment Station

3909 Halls Ferry Road, Vicksburg, MS 39180-6199
8. PERFORMING ORGANIZATION REPORT NUMBER

Technical Report EL-99-9
9. SPONSORING/MONITORING AGENCY NAME(S) AND ADDRESS(ES)

Environmental Security Technology Certification Program Office 901 North Stuart Street, Suite 303

Arlington, VA 22203

\section{SUPPLEMENTARY NOTES}

Available from National Technical Information Service, 5285 Port Royal Road, Springfield, VA 22161.

12a. DISTRIBUTION/AVAILABILITY STATEMENT

Approved for public release; distribution is unlimited.
10. SPONSORING/MONITORING AGENCY REPORT NUMBER

13. ABSTRACT (Maximum 200 words)

Monitored natural attenuation (MNA) is a remedial alternative for explosives-contaminated groundwater at sites where a decline in contaminant mass can be demonstrated to occur at a rate sufficient to ensure the protection of potential receptors. MNA is not a "no-action" alternative, but requires careful characterization of the site hydrogeology and contaminant distribution, long-term monitoring of groundwater, and groundwater modeling to conceptualize the contaminant plume and to predict future migration and attenuation. MNA in the context of the demonstration described herein does not include intervention to promote natural processes.

Demonstrating that MNA is a viable remedial alternative requires gathering a "weight of evidence" that natural processes are sufficient to protect receptors of concern within a reasonable time frame. Explosives are subject to several attenuation mechanisms that effectively reduce concentrations in natural systems. Some of these processes have been defined, while other are poorly understood. MNA relies upon quality site characterization data, carefully conducted long-term monitoring, and groundwater modeling for contaminant conceptualization and long-term predictions of contaminant fate. Determining

(Continued)

\section{SUBJECT TERMS}

Explosives

Groundwater modeling

Groundwater monitoring
Intrinsic remediation

Natural attenuation

RDX
15. NUMBER OF PAGES 24

16. PRICE CODE

\section{SECURITY CLASSIFICATION OF REPORT \\ UNCLASSIFIED \\ 18. SECURITY CLASSIFICATION OF THIS PAGE UNCLASSIFIED}

Standard Form 298 (Rev. 2-89) Prescribed by ANSI Std. Z39-18 298-102 


\section{ABSTRACT (Concluded).}

attenuation rates for explosives requires demonstration of declining mass over time, and conservative extrapolation of attenuation capacity and microbial degradation potential from the laboratory to the field.

This demonstration was designed to define and optimize the data collection and processing procedures for evaluation, selection, and implementation of MNA for explosives. The demonstration was conducted at a former waste disposal lagoon site at the Louisiana Army Ammunition Plant, Minden, LA. Thirty wells were monitored quarterly over a 2-year period. A cone penetrometry sampling event was also conducted to refine the conceptualization of the site hydrogeology and to collect aquifer material for development of microbial biomarker techniques for tracking attenuation processes. A conceptual model of the contaminant plume was developed and a numerical model was used to predict future plume migration and mass.

Overall costs of the demonstration were approximately $\$ 4$ million. Refinements in sampling protocols, biomarker techniques, and modeling generated data that were sufficiently reliable for measuring and projecting trends in contaminant mass over time.

The overall cost (including pretreatment, treatment, and after-treatment costs) of MNA is projected to be about 25 percent lower than the cost of in situ bioremediation, and about 50 percent lower than the cost of pump-and-treat using activated carbon adsorption over 20 years (Pennington, Zakakhani, and Harrelson 1999; Member Agencies of the Federal Remediation Technologies Roundtable 1995). However, if the treatment time is extended and only treatment costs (exclusive of pretreatment and after-treatment costs) are used, cost savings from MNA over these other technologies increase over time. Treatment costs of MNA were 82 percent less than costs of in situ bioremediation and 88 percent less than costs of pump-and-treat remediation after 60 years. Therefore, the time required to achieve cleanup goals contributes significantly to the long-term savings of MNA. 